\title{
ACTIVATION OF INVESTMENT ACTIVITY OF AGRICULTURAL ENTERPRISES IN MARKET CONDITIONS IN UKRAINE
}

\author{
Yana Goncharuk \\ Bukovina University, Chernivtsi, Ukraine
}

(C) MESTE NGO

JEL Category: D92, 013, Q13

\begin{abstract}
In the article the financial flows of agricultural enterprises in the region are analyzed in order to improve their management. The necessity to develop methods of improving the existing definition of the optimal structure of financial flows of agricultural producers is due to theoretical and practical interest in the content and the basic elements of financial flows of agricultural enterprises. Through economic activity, farmers most actively interact with the banking sector. To mobilize a large part of assets, credit institutions provide financial services to business entities. In addition, they make a redistribution of financial flows, on the one hand, due to customers' obligations, on the other - in order to obtain financial benefits and increase their income. At the same time, counter financial flows of agricultural enterprises of the region that are being formed have a certain level of net flows. The greater the balance of oncoming flow is, the more globally the economic conditions change. Also discussed in detail are the innovative aspects of agriculture production and various aspects of logistics in agriculture. An effective logistics system associated with $A I C$ is meant to optimize supply chains from primary product through processing to the final consumer.
\end{abstract}

Keywords: management, financial flows, efficiency, agricultural enterprise, analysis, regulation

\section{MANAGEMENT OF FINANCIAL FLOWS OF AGRICULTURAL ENTERPRISES IN THE REGION.}

The need for areas of improvement in existing methods for determining the optimal structure of financial flows of individual agricultural producers is due to the theoretical and practical interest in content and basic elements of financial flows of agricultural enterprises in the region.

Determination of financial flows in practice is usually based on the sum of separate financial

Address of the author:

Yana Goncharuk

䤵 yanick22@mail.ru flows of large agricultural enterprises and organizations. In modern economic literature, this method is preferred.

In our view, the definition of financial flows of regional AIC as the sum of flows of leading agricultural companies in the region can be used in cases when the economy of the region is formed by the activity of one or more businesses. However, in the current economic situation financial flows of regional AIC have more diverse structure, reflecting not only the flow of agricultural enterprises, but also the population, farms, local authorities, local governments and the state budget. All formulas measuring financial flows are constructed by the selection of data from 
companies' balance sheets or their financial and statistical statements.

At the same time, as defined in the economic literature, the balances in the accounts of agricultural enterprises (AIC) represent the accumulation of reserves or margins on a specified date. The value of balances in some way dependent on the financial and industrial activities of an economic entity can not be used as an objective assessment of the financial flows. Significant statistical activities of both financial and production activities of AIC are based on the determination of account balances, the values of receipts and payments on a certain date. This method is necessary to determine the absolute values of the indicators, and to ensure their comparability, to identify the changes in the value of assets and liabilities as a result of the dynamics of market prices and the exchange rate of hryvnia against foreign currencies.

But the definition of financial flows of agricultural enterprises in the region requires a different approach, which should reflect its focus not on one single transaction of agricultural products, but on the totality of economic transactions carried out in a period of time in the region.

Therefore, it is appropriate to consider all business activities of agricultural enterprises in the region as debit and credit turnovers, which will better identify the direction of financial flows in the whole.

In our opinion, there are such important principles of effective management of financial flows of agricultural enterprises in the region as:

- comprehensive detection of virtually all the funds involved in the economic activities of the region;

- methodological consistency;

- the unity and consistency of tools and methods for determining the financial flows of agricultural enterprises.

Taking into account the flow of almost all the resources involved in economic transactions is enabled by the process of determining financial flows of agricultural enterprises in the region, which is built on information about the flow of funds in the accounts of the banking sector in the regional economy. In this case, the current system of economic accounting transactions and mutual economic agents implies that they are both debtors and creditors. That's why there is a set of economic agents.

Through economic activity agricultural enterprises in the most active way interact with the banking sector. To mobilize substantial part of the assets of credit, organizations provide financial services to business entities. In addition, they make the redistribution of financial flows, on the one hand, due to clients' obligations, on the other hand, in order to obtain financial benefits and increase their income. Thus, counter financial flows of agricultural enterprises of the region have a certain level of net flows. The greater the balance of oncoming flow is, the more globally the economic conditions change. The increasing financial operations, growth of investment opportunities in agricultural enterprises and increasing agricultural production is due to the revitalization of the institutional sectors of the regional economy, with rising deposit operations in credit and financial institutions, expanding the flow of payments to budgets of all levels. All changes are almost simultaneously displayed on the size of the resource base of the banking sector of economic activity in the region: they are reflected on the amount of the resource base of the banking sector in the region: i.e. increasing lending operations of banks, growing number of current and settlement accounts of agricultural enterprises, in all types of deposits, and in increasing issue of securities. Naturally an increase in turnover in all types of operations or cash flows of agricultural enterprises of the region takes place. However, some of the financial flows are not involved in credit and payment operations of the banking sector in the region. Typically, these funds are sent to the shadow economy.

Nowadays agro-industrial complex of Ukraine is in crisis, which caused negative effects of agrarian reform, inflationary pressures, fiscal policy, financial inability of agricultural producers, and lack of government support. In these circumstances, it is becoming important for the national agro-industrial complex to activate investment in enterprises of agro-industrial production. The solution of this problem will help to overcome the economic crisis recovery and to grow productive capital, increasing efficiency of product competitiveness and resolving a range of socio-economic issues AIC (Parkhomets, 2012). 
In the first quarter of 2013, foreign investors invested 1.56 billion dollars U.S. in the economy of Ukraine direct investment (equity), which is 1.8 times more than in the corresponding period of 2012 (885.1 million dollars U.S.). Investments came from 136 countries. The five investor countries included Cyprus - 32.4\% (17.69 billion dollars), Germany - $11.1 \%$ (6.12 billion dollars), Netherlands - 9.7\% (5.26 billion dollars), Russia 6.9\% (3.81 billion dollars), Austria - 5.8\% (3.42 billion dollars). In the next two years, the state will provide assistance to almost all sectors of agriculture. This support will come from the State Program intensification of economic development for 2013-2014. Implementing the provisions of this document, Ukraine will grow gross production in agricultural sector to 260 billion USD per year. Budget revenues will grow to 48 billion UAH.

To achieve these ambitious goals, the Ministry of Agriculture in cooperation with central and local executive authorities continues to perform a number of tasks as part of economic reforms and the State Program of economic activation for 2013-2014. Because of this, food security in the state will be $100 \%$ ensured. Investment climate in the agricultural sector will be improved and its productivity increased. Thus, the production of gross agricultural output will be increased to 260 billion $\mathrm{UAH}$, exports of agricultural products will reach 22 billion dollars a year. This will increase the revenues of the consolidated budget to 48 billion UAH. Lack of long-term loans should be considered as the main factor in reducing the activity of the investment process in the agricultural sector. Due to the lack of pledge, seasonality and risks of agricultural producing, banks cannot provide medium- and long-term loans to the agricultural enterprises (Y.M. Ostapchuk, 2014).

The main source of activating the investment in enterprises in agricultural areas are own funds, bank loans and government subsidies, credit cooperatives and foreign investments. In the overall structure of sources of financing investment activities the most important are funds of enterprises and organizations, which is an average of $66 \%$. This funding source dominates the total volume of revenues from other sources such as state and local finance, loans, foreign investment and other investment sources (Kabanov, 2010).

\section{TECHNIQUES AND TOOLS OF AGRICULTURAL RISK CONTROL}

Agrarian reforms and the establishment of market relations, the change in forms of ownership and management significantly increase the uncertainty of the socio-economic processes in agriculture and, therefore, enhance the impact of the risks agricultural businesses are exposed to. The impact of macro-economic decisions on the activities of each farmer is increasing. Risk is an objective element of entrepreneurship. But agriculture is much greater risk due to characteristics unique to this type of business. Seasonality of production, long-term circulation of capital, a significant dependence on climatic conditions, a large number of businesses, the impossibility of coordination of all activities - this is not a complete list of all the factors.

All available mechanisms and instruments to manage agricultural risk management to minimize risks and protect farmers from their effects can be divided into three levels:

The first level - tools used by farmers themselves - effective agro technologies, rational use of fertilizers and plant protection products, reasonable provision of equipment and highly qualified specialists, diversification of production and cooperation, creation of marketing schemes, vertically oriented enterprises etc.

The second level - to use tools a farmer must apply to the private sector.

The third level - the macro-economic methods that are based on regulatory government policies at agricultural markets and government programs to support agrarian sector make up the third level in the system created to minimize the risks (llyashenko, 2004).

Let us look at the existing mechanisms and instruments used to minimize production and market risks.

\subsection{Diversification of agricultural production}

Diversification, as well as specialization, is a tool to reduce the existing risks and, therefore, maintain development of an enterprise. To minimize the risks and obtain stable financial performance agricultural enterprise may opt for specialization, or maintenance of existing 
production methods and diversification of its activities.

There are several types of diversification:

- Traditional agricultural diversification;

- Diversification by producing alternative products;

- Manufacture of non-agricultural products and services.

Traditional agricultural diversification involves the processing of agricultural products.

Diversification by means of production of alternative products is growing non-traditional crops and animals.

Diversification by producing non-agricultural products and services.

\subsection{Financial and credit support}

Currently, the level of financial and credit infrastructure is a major issue in agriculture. With the lack of own financial resources and their limited involvement agricultural businesses cannot conduct effective production and ensure profitability.

Questions of ownership of agricultural land, undeveloped land markets, significant deterioration and moral obsolescence of fixed assets remain unresolved. The absence of a land market makes it impossible to use it as loan collateral, which hinders the development of longterm loans.

\subsection{Agricultural insurance}

The main purpose of agricultural insurance is to compensate farmers' harvest losses arising from the impact of climatic risks. Another purpose of insurance is to improve the financial situation of farmers and to ensure better access to credit.

The current financial strength of domestic insurance companies is not sufficient to pay to farmers when the insurance case is caused by the act of systemic risks (Andriychuk, 2012).

\subsection{Problems in AIC Logistics}

Recently, logistic system has been increasingly used in the practice of agricultural enterprises. The concept of agricultural logistics system is derived from the specific term "logistic system" and general term "system".

System (from Greek - whole, composed of parts, links) is the set of elements that are in relations and connections with each other and form a certain integrity, unity.

Logistic system is an adaptive (adaptive or selforganizing) system with inverse connections, which performs logistics functions and logistics operations. As a rule, logistic system consists of various subsystems (elements), characterized by well-developed links with the environment.

Agricultural logistics system is logistic system that operates in the agricultural sector. Logistic systems correspond to the conventional notion of system since they consist of system-elements; elements are interrelated and interdependent; links ordered; links form a structure with predetermined properties.

Systematic approach involves consideration of all elements of the logistics system as interconnected and interacting to achieve the common goal of management. A distinctive feature of the system approach is optimizing operation of not separate elements, but logistics system as a whole, resulting in the appearance of the so-called synergistic effect. Thus, with the systematic approach to the business organization, logistics system is a relatively stable set of links (structural/ functional business units, suppliers, customers, logistics intermediaries) interconnected and united by a common logistics management process to implement corporate strategies of business organization.

Properly organized logistics system of the company is crucial to competitive advantage, since it is aimed at reducing inventories, acceleration of working capital, reducing production costs and general logistics costs, optimal use of storage and transport capacities, and providing consumers with high-quality logistics services.

Agribusiness in comparison with other activities is characterized by rather high risk, primarily associated with the availability and quality of raw materials, making implementation of logistics technology relevant for private, regional and state enterprises. In this regard, logistics of agricultural sector companies requires a systematic approach 
(Layl, Spenser, \& Sayn, 2005, p. 5), implementing which well-tuned management mechanism is formed by key characteristics of the efficiency of flow of orders, products (raw materials), finance, as well as their organization and maintenance. In this case, flow control is carried out, which generates processes and operational cycles in general. The specificity of the agricultural production system allows to identify the main characteristics of logistics AIC: order fulfillment and customer service channels organization, forecasting demand for agricultural products and the volume of consumption analysis, inventory management products (raw materials) and minimizing losses due to unsteady supply, communication links and availability of information space for steady orders, depots maintenance and storage cost minimization, traffic management, optimization of the geographical location of production and warehouse facilities, the management of service; financial management, the management of human resources.

Execution of customer orders and organization of service channels are one of the basic characteristics of AIC efficient logistics, as they reflect the efficiency of the operation and organization of the sales in order to meet the client needs at the right time with the necessary product at minimal costs. Due to limitations in terms of storage, agricultural products require compliance with trade organizations in specific terms of sale, and, in particular, direct sales from local producers, firm trade through its own network, sales through intermediaries etc.

Forecasting demand and consumption analysis describe the possibility of selling the products according to expected needs. Seasonality, limited resources, and weather risks in particular make the pricing of agricultural products not only dependent on inflationary expectations and income, but also on the production technology.

Effective inventory control of products (raw materials) minimizes losses due to unsteady supply and unplanned stock movement. Given the seasonality of operating cycle, inventory control mechanisms solve the problem of the frequency of sales delivery and providing raw materials to processing enterprises. Creating stock reserves takes place in various ways: serial stock, cyclical stock, stock utilization, stock security warning margin (Kristofer \& Pek, 2005, p. 8).. Stock maintenance requires costs to maintain physical properties of stock (depreciation cost, heating, electricity), with invested assets (assets withdrawn from circulation until the implementation of the enterprise), with the risks of the stock realization (taking into account the possibility of lack of demand).

Communications links and availability of information space ensure coordination of the flow of orders. The ability to provide timely access to information sources increases the competitiveness of the logistics system.

The introduction of modern information technologies in logistics needs to address the following issues: minimizing the time of your order execution, consolidating the orders; personification access, storage of large amounts of information, minimizing the processing time in transaction orders.

Maintenance of warehouses is connected with the choice of storage facilities, and especially deciding on an alternative support of operating own warehouses or rental payment for the leased premises. Also the efficiency of warehouse activities organization storage operations is largely determined by unloading, downloading, packaging and so on. The necessity for optimal use of storage space requires the calculations of the number of storage units, their size and usability. Given the fact that in most cases the products of agriculture have short shelf life, one should focus on the location of warehouses close to the point of sale.

The efficiency of traffic management is aimed at minimizing transportation costs. The essence of logistics traffic management is the optimal way of transportation from the supplier to the consumer, taking into account the size of the possible cases of traffic, capacity of transshipment points, the current cost of the vehicle, etc (Stock J.R. Lambert D.M., 2005, p. 73-84).

Financial flows in AIC logistics involve investment to expand reproduction of agricultural production. Increasing amounts of investments require more sophisticated mechanism of their use to ensure investor protection, control of obligations, the implementation mechanisms of insurance, compensation of loan rates, lower investment risks at various stages of production and others. 
Managing human resources is effective because of targeting specific people to improve the quality of performed functions. One prospect is the positioning of human resources in the management hierarchy providing compliance with relevant competence, comprehending human ability to perform certain work regardless of race, age, cultural affiliation, (Porter, 2005, p. 345).

Various aspects of AIC logistics reveal opportunity for improving the logistics of agricultural enterprise being a critical success factor in agro-business and promoting production of competitive agricultural products. An effective AIC logistics system is inextricably linked to probable profit due to optimization of supply chains as a vertically integrated agricultural farm from primary producer through processing to the final consumer.

\section{INNOVATIVE ASPECTS AGRICULTURE PRODUCTION.}

The current trend of increasing profitability of all agricultural enterprises activities is inexplicably combined with drop in the number of main types of equipment in the period of market reforms. Natural resources consumed in the production of agricultural products are not being reproduced and as a result areas with fertile soil are shrinking as well as areas of meliorated land. In recent years the usage of organic fertilizers has decreased, which led to a decrease in humus content and deterioration of other characteristics of productive arable land.

Unfortunately, we cannot rely on reproduction of labor as the workers' salary in this sector is one of the lowest in the economy, reaching only $70 \%$ of the average wage in the country in 2011 (Vlasenko, 2012, p. 31). This fact determines the intense outflow of working population from agriculture in recent years, which is not compensated by using highly efficient equipment and intensive technologies. Obviously, agricultural production, based on the preferential use of the natural soil fertility, can not last forever. Lack of nitrogen, phosphorus, potassium and other nutrients creates disbalance and quality characteristics of crops deteriorate. Thus, in recent years the amount of harvested food grain has been decreasing and figures in gross harvest have been secured mainly by feed wheat, rye and barley.
In domestic agriculture both cutting edge and primitive methods of production are present, from precision techniques (e. g., precision agriculture using satellite navigation techniques) to the archaic, in which the basic technological standards are not met. We must add the poor material and technical equipment of many farms, which reinforces the lack of operational discipline.

Initiative leaders of agricultural enterprises invite leading scientists to their production facilities, continuously monitor the latest developments in agriculture, systematically study and send their experts to study in the best educational and research centers, business schools. This leaders' attraction to progress has become as much a reality as the almost complete lack of interest or desire to make radical changes in the rest of the farmers.

Nowadays laborious agricultural production is concentrated in private households who are unable to meet the needs of the market with highquality standardized products. There is excessive concentration of land in the use of large agricultural units (agricultural holdings) that are engaged in less labor-intensive, and highly profitable production. Against the background of the benefits of agricultural holdings in the form of intensification of agricultural production and increasing the export potential of agriculture, their further development is threatening, primarily due to growing export of certain crops, which greatly deplete the soil, and exports of mainly grain and oil.

Such rural development scenarios reflect the paradoxes of agricultural policy at the macroeconomic level. Recent years have been marked by stable growth in the gross Ukrainian agricultural produce. At the same time, there has been considerable increase in food imports. Thus, given the increase in production of domestic agricultural products (even considering the inflation) and repeated increase in food imports in this century the consumption of basic foodstuffs per capita still has not reached indicators of 1990.

\section{CONCLUSIONS}

Thus, on the one hand, there is growth in agricultural production. On the other hand, due to fundamental reasons lasting and stable development of the agricultural sector cannot be 
sustained. These contradictions require deep analysis and, most importantly, taking immediate action to consolidate the existing positive trends, primarily of institutional character, agribusiness must not shift toward unwanted processes and enormous potential competitiveness of the industry must not lose opportunity to develop the national economy.

The main reason for the low innovation activity of domestic producers is considered to be the lack of economic interest in the mechanisms of implementing innovations into production. Enterprises conduct their own innovation activities due to limited financial resources to solve scientific and technological problems. The technical level of domestic production declines, implemented innovations are meant to improve the existing situation but they do not require significant costs. Also, the level of of scientific developments implementation is being reduced and loss of scientific potential in the field of genetics (seeds and breeding) is observed. Agricultural sector faces extremely complex task of transition from technologic to a postindustrial degradation mode of production. Scientific and technological progress and using the advanced technologies, combined with a set of organizational and economic measures are the basis for further development of agriculture in our country, which is not only the most important part of the economy, but also the foundation of national security.

Innovation activity in modern conditions has become a major factor in the development of agriculture, and its implementation is the only way to overcome the crisis and ensure sustainable development of agricultural production in our country. In conditions of socio-economic changes and increasing pressures of the global economy, our country should make accelerated transition to innovative way of development of agriculture, in order to restore this strategically significant sector of the economy on a new technical and technological basis, which corresponds to modern trends.

\section{WORKS CITED}

Andriychuk, V. H. (2012). The economy of agricultural enterprises. Kiev: KNEU.

llyashenko S.M. Economic risk: course book / llyashenko S. M. - K .CSM, 2004. - 220 p.

Kabanov, V. H. (2010). Enhancing financial investments as part of the strategy of stabilization and growth. Finance of Ukraine (5), 39-47.

Kristofer, M., \& Pek, K. (2005). Marketing logistics. Moscow: Publishing house "Technology".

Layl, M., Spenser, M., \& Sayn, M. S. (2005). Competence at work. Trans. from English. Moscow: NÍRRO.

Ostapchuk Y.M. Agriculture of Ukraine [statistical book] - K .: State Statistics Service of Ukraine, 2014. $-374 \mathrm{p}$.

Parkhomets, M. K. (2012). Enhancing investment in AIC. Innovatsiyna ekonomika. Ukrainian scientificproduction magazine, 9(35), 3-8.

Porter, E. M. (2005). Competitive strategy: Methodology Analyzing of Industries and competitors: Trans. from English. Moscow: Al'pina Biznes Buks.

Stock J.R. Lambert D.M. Strategic logistics management: Trans. the 4th Eng. ed. - M .: INFRA-M, 2005 $-197 \mathrm{p}$.

Vlasenko, M. (Ed.). (2012). Agriculture of Ukraine [statistical book]. Kiev: State Statistics Service of Ukraine.

Received for publication: $\quad 03.02 .2014$

Revision received: $\quad 10.05 .2015$

Accepted for publication: $\quad 22.05 .2015$ 


\section{How to cite this article?}

Style - APA Sixth Edition:

Goncharuk, Y. (2015, July 15). Activation of investment activity of agricultural enterprises in market conditions in Ukraine. (Z. Čekerevac, Ed.) MEST Journal, 3(2), 45-52. doi:10.12709/mest.03.03.02.05

Style - Chicago Sixteenth Edition:

Goncharuk, Yana. 2015. "Activation of investment activity of agricultural enterprises in market conditions in Ukraine." Edited by Zoran Čekerevac. MEST Journal (MESTE) 3 (2): 45-52. doi:10.12709/mest.03.03.02.05.

Style - GOST Name Sort:

Goncharuk Yana Activation of investment activity of agricultural enterprises in market conditions in Ukraine [Journal] // MEST Journal / ed. Čekerevac Zoran. - Belgrade : MESTE, July 15, 2015. - 2 : Vol. 3. - pp. 45-52.

Style - Harvard Anglia:

Goncharuk, Y., 2015. Activation of investment activity of agricultural enterprises in market conditions in Ukraine. MEST Journal, 15 July, 3(2), pp. 45-52.

Style - ISO 690 Numerical Reference:

Activation of investment activity of agricultural enterprises in market conditions in Ukraine. Goncharuk, Yana. [ed.] Zoran Čekerevac. 2, Belgrade : MESTE, July 15, 2015, MEST Journal, Vol. 3, pp. 45-52. 